\title{
Erratum to: Effect of livestock grazing and human uses on herbaceous species diversity in oriental beech (Fagus orientalis Lipsky) forests, Guilan, Masal, northern Iran
}

Side Sadat Ebrahimi • Hassan Pourbabaei • David Potheir Ali Omidi • Javad Torkaman

(C) Northeast Forestry University and Springer-Verlag Berlin Heidelberg 2014

Erratum to: Journal of Forestry Research, (2014) 25(2): 455-462

DOI 10.1007/s11676-014-0476-8

The original version of this article unfortunately contained one mistake in first author's name. The first author's name, "Side Sadat Ebrahimi", actually should be Sepide Sadat Ebrahimi.

The online version of the original article can be found at http://dx.doi.org/10.1007/s11676-014-0476-8

Sepide Sadat Ebrahimi (- Hassan Pourbabaei, Javad torkaman

Department of Forestry, Natural Resource Faculty, University of Guilan, Somehsara, P. O. Box 1144, Guilan, Iran.

E-mail: sepid6638@yahoo.com

David Potheir

Centre d'étude de la forêt (CEF), and Département des sciences du bois et de la forêt, Pavillon Abitibi-Price, 2405 rue de la Terrasse, Université Laval, Québec, QC G1V 0A6, Canada.

Ali Omidi

Department of Forestry, Natural Resources Office, Guilan, Iran.

Corresponding editor: Zhu Hong 